\title{
Minimum inhibition concentration and anti- fungal contact time of quaternary ammonium and ethylenediaminetetraacetic acid (EDTA) mixture towards Candida albicans isolate
}

\author{
Ellizabeth Yunita, Karlina Hardjawinata, Warta Dewi \\ Department of Oral Biology Faculty of Dentistry Universitas Padjadjaran
}

\begin{abstract}
The aim of this study is to determine the Minimum Inhibitory Concentration (MIC) and the exposure time of the combination of quaternary ammonium compound with EDTA towards Candida albicans isolates from the 5 upper acrylic removable complete dentures. This experimental laboratory study was conducted based on a serial dilution of the combination of quaternary ammonium compound with EDTA towards Candida albicans in 3 replications and statistically analyzed according to Kruskal-Wallis method. The result showed that the MIC of the combination of quaternary ammonium compound with EDTA towards Candida albicans was in $1 / 8000$ concentration with minimum 8 hours exposure time. This study concluded that the combination of quaternary ammonium compound with EDTA had an antifungal activity towards Candida albicans at 1/8000 concentration in 8 hours exposure time.
\end{abstract}

Key words: quaternary ammonium, ethylenediaminetetraacetic acid (EDTA), antifungal effect, Candida albicans.

।

\section{INTRODUCTION}

In the mouth, artificial teeth always contact the saliva that it is covered by saliva pellicles. The pellicles that contain protein can bind oral microorganism so that it is attached on the artificial denture surface. ${ }^{1}$

The artificial dental material can absorb Candida species and becomes an additional location as the living place for the microorganism. Candida albicans is an opportunistic fungus that is most frequently isolated from human specimen. The attachment of this species in acrylic and the poor oral hygiene can increase the risk of candidiasis for most artificial denture users, known as denture stomatitis. This inflammation is often found in the upper artificial full denture due to the lack of saliva flow to the tissue surface under the base that fungus can grow freely in the space between the denture and the mucous. The bigger the upper artificial denture adaptation to the palate is, the higher the number of fungus growing in the location. ${ }^{2-5}$

Davenport ${ }^{6}$ stated that C. albicans population on the denture surface that faces the mucous is more than that found in the mucous, due 
to the anatomical surface of the upper artificial denture. The presence of the denture helps the development of saprophyte environment. The C. albicans on the lower artificial denture surface that faces the mucous is rarely found because this fungus can be carried away by saliva flow and tongue movement. ${ }^{4,6}$

Sheen and Harrison ${ }^{7}$ and Greenberg and Glick ${ }^{4}$ suggested that the use of artificial denture cleaner can help in controlling or removing artificial denture plaque, mucous inflammation and denture stomatitis.

Quaternary ammonium disinfectant is an active cation detergent that has a bactericide property and is more fungistatic than fungicide. The quaternary ammonium has a relatively broad work spectrum. ${ }^{8}$ The work power is stronger for Gram positive bacteria than Gram negative bacteria. ${ }^{9-12}$ In alkali environment, the bactericide work increases and it disappears completely in acid environment with a $\mathrm{pH}<3 .{ }^{10}$ This compound has been used for years as a solution for non heating sterilization. ${ }^{13}$ In addition, there are other properties that make quaternary ammonium a beneficial disinfectant including the absence of phenol, iodine, active chlorine, mercury, or other heavy metal content that tend to be toxic. It is also odorless, colorless, relatively stable and non toxic when it is used in the recommended concentration..$^{14,15}$

Ethylenediaminetetraacetic acid (EDTA) can maintain a stable compound form. Addition of EDTA will increase other antimicrobial compound potential to fight Gram negative bacteria. EDTA has an antimicrobial action mechanism by binding divalent metal ions such as $\mathrm{Ca}^{2+}$ and $\mathrm{Mg}^{2+}$ that makes microorganisms unable to replicate and reproduce. The divalent metal ions are very important for stabilizing and replicating the outer layer of bacterial cell wall. EDTA can also weaken fungal cell wall. In several cases, EDTA can be used for destabilization and to remove the outer lipopolysaccharide layer. ${ }^{12,16,17}$

By evaluating the work of quaternary ammonium towards Gram positive bacteria and EDTA addition that is able to improve the potential of the antimicrobial compound to fight Gram negative bacteria, it is expected that the mixture of the two materials can work more effectively.

This study is aimed at improving the use of quaternary ammonium mixture use with ethylenediaminetetraacetic acid (EDTA) according to the predetermined concentration and time as a disinfectant material for removable upper acrylic artificial full denture that is used in patients in dental clinics or in everyday practice.

\section{MATERIALS AND METHODS}

This study is a laboratory experimental study to define MIC and contact time of an effective quaternary ammonium and EDTA mixture through serial dilution for fighting $C$. albicans isolates of removable upper acrylic artificial full denture. The results of the study were tested statistically using Kruskal-Wallis method.

The population for this study is all quaternary ammonium and EDTA mixture in the world. The criterion of the test material population is quaternary ammonium and EDTA mixtures in Indonesia. The sample used is the quaternary ammonium and EDTA mixtures produced by PT Magna.

As the test fungus, C. albicans is used with a selection criteria of being presence in removable upper artificial full denture that has been used for more or less 12 hour according to the average denture wear in one day from subjects whose age is more than 50 years old.

The study was performed from February to September 2007 at the Microbiology Laboratory of the Faculty of Dentistry, Universitas Padjadjaran, Jatinangor.

The sampling of the test materials (TM) was performed by soaking the upper acrylic artificial full denture that has been used for more or less 12 hours according to the average denture wear in one day. The soaking was performed using $75 \mathrm{ml}$ sterile aquadest solution for 30 minutes in a sterile petri disc that has a diameter of 10 $\mathrm{cm}$ and height of $2 \mathrm{~cm}$. To observe the microbe presence in the rinsed material, 1 loop TM was removed and prepared on an object glass, fixated, and then stained using Gram staining method for microscopic examination. The rest of the TM was diluted 100x using 2 test tubes. In the first test tube, $0.5 \mathrm{ml} \mathrm{TM}$ and $4.5 \mathrm{ml}$ sterile aquadest were mixed until a homogenous solution was reached. $0.5 \mathrm{ml}$ solution from the test was removed and placed into the second tube. $4.5 \mathrm{ml}$ sterile 
aquadest was then added to this tube. After the second test tube was shook until a homogenous solution was reached, $0.1 \mathrm{ml}$ of the materials was taken and cultured using lining method in SGA. The culture was then incubated in a temperature of $37^{\circ} \mathrm{C}$ for $18-24$ hours.

An examination of culture colony characteristics in SGA was performed after the incubation process. The colony with a characteristic of a round, smooth, convex, with a yellowish white and yeast like smell was determined as Candida colony suspect. This colony was then isolated and examined microscopically based on Gram staining.

The microscopic examination showed Candida characteristics including round to oval shape, a size that is bigger than bacteria $(3 \times 5 \mu \mathrm{m})$ and Gram positive nature which is then identified using fermentation test towards glucose, maltose, saccharose and lactose carbohydrate culture with phenol red as the indicator.

The dilution of the quaternary ammonium and EDTA mixture up to 100x was performed using 3 test tubes. 10x dilution was performed by mixing $4.5 \mathrm{ml}$ sterile aquadest with 0.5 quaternary ammonium and EDTA mixture in tube A. To get $100 x$ dilution, in tube $B 4.5 \mathrm{ml}$ sterile aquadest was mixed with $0.5 \mathrm{ml}$ solution from tube $A$. For 1000x dilution in tube $C, 4.5 \mathrm{ml}$ bullion is mixed with $0.5 \mathrm{ml}$ solution from tube $B$. The mixture in tube $C$ was then referred as standard solution.

To determine the MIC of quaternary ammonium and EDTA mixture towards the growth of C. albicans colonies, a serial dilution for eight different concentrations along with positive control and negative control were made. Two serial dilution for quaternary ammonium and EDTA mixture used was for $1 / 1000,1 / 2000,1 / 4000$, $1 / 8000,1 / 16000,1 / 32000,1 / 64000$, and $1 / 128000$ concentrations.

MIC of this test material is determined based on the two serial dilution method in 10 tubes. 2 $\mathrm{ml}$ of bullion is filled into tube 2 to 8 and 10 . In the first tube $4 \mathrm{ml}$ solution from tube $C$, which is the standard solution gained from 1000x dilution, was placed. $2 \mathrm{ml}$ of this solution was pipetted into tube 2 and then shook until a homogenous condition was reach. After that $2 \mathrm{ml}$ of tube 2 solution was then pipetted into tube 3 and was shook until a homogenous condition was reached. Next $2 \mathrm{ml}$ of tube 3 solution was then pipetted into tube 4 and was shook until a homogenous condition was reached, and so on until tube 9 was done. The bullion suspension and C. albicans that was made equal to Mc. Fahrland turbidity of 0.5 was pipetted, each was $0.1 \mathrm{ml}$, to tube 1 to 8 and 10. Therefore, tube 9 only contained bullion and quaternary ammonium and EDTA mixture and it was used as the negative control and tube 10 which contained bullion and $\mathrm{C}$. albicans became a positive control (Tab.1).

After that, all tubes were incubated in a temperature of $37^{\circ} \mathrm{C}$ for 18-24 hours. On the next day, the turbidity of each tube was noted and 1 loop from each tube was taken to be cultured sectorally in SGA which was then incubated using the same temperature and time. The sectoral culture was then observed to see the number of colonies grew on the media. MIC was shown among sectors that showed the least colony growth and

Table 1. Serial dilution for quaternary ammonium and EDTA mixture in MIC test.

\begin{tabular}{ccccc}
\hline Tube & Glucosa Bullion & $\begin{array}{c}\text { Quaternary ammonium \& } \\
\text { EDTA mixed solution }\end{array}$ & Concentration & $\begin{array}{c}\text { C. albicans suspension } \\
\text { equals to Mc. Fahrland 0.5 }\end{array}$ \\
\hline 1 & - & $4 \mathrm{ml}$ of standard solution (tube C) & $1 / 1000$ & $0.1 \mathrm{ml}$ \\
2 & $2 \mathrm{ml}$ & $2 \mathrm{ml}$ from tube 1 & $1 / 2000$ & $0.1 \mathrm{ml}$ \\
3 & $2 \mathrm{ml}$ & $2 \mathrm{ml}$ from tube 2 & $1 / 4000$ & $0.1 \mathrm{ml}$ \\
4 & $2 \mathrm{ml}$ & $2 \mathrm{ml}$ from tube 3 & $1 / 8000$ & $0.1 \mathrm{ml}$ \\
5 & $2 \mathrm{ml}$ & $2 \mathrm{ml}$ from tube 4 & $1 / 16000$ & $0.1 \mathrm{ml}$ \\
6 & $2 \mathrm{ml}$ & $2 \mathrm{ml}$ from tube 5 & $1 / 32000$ & $0.1 \mathrm{ml}$ \\
7 & $2 \mathrm{ml}$ & $2 \mathrm{ml}$ from tube 6 & $1 / 64000$ & $0.1 \mathrm{ml}$ \\
8 & $2 \mathrm{ml}$ & $2 \mathrm{ml}$ from tube 7 & $1 / 128000$ & $0.1 \mathrm{ml}$ \\
9 & - & $2 \mathrm{ml}$ from tube 8 & $1 / 128000$ & - \\
10 & $2 \mathrm{ml}$ & - & - & $0.1 \mathrm{ml}$ \\
\hline
\end{tabular}


the sectors that did not show any fungal colony growth. Each test fungus was tested repeatedly for 3 times using the same method.

The contact time test was performed by diluting quaternary ammonium and EDTA solution according to the predetermined MIC. Into the tube, $0.1 \mathrm{ml} \mathrm{C}$. albicans suspension with a turbidity equals to Mc Fahrland 0.5 was placed and a culture was made on SGA for a contact time of $1 / 4$ hour, $1 / 2$ hour, 1 hour, 2 hours, 4 hours, and 8 hours according to the habit people usually soak their removable upper acrylic artificial full denture. Each test fungus was treated three times using the same method.

The microorganism growth in SGA was observed after being incubated in a temperature of $37^{\circ} \mathrm{C}$ for $18-24$ hours. Each culture in SGA that showed a minimum colony growth in a shortest contact time was selected as the most effective contact time.

\section{RESULTS}

The results from the serial dilution that had been incubated show different turbidity level for each tube. The solution in tube 1 and 3 were as clear as the negative control while the solution of tube 4 was started to be clouded and the turbidity is increasing in tube $5,6,7$, and 8 , respectively, similar to the positive control.

The results of sectoral culture in SGA show that no C. albicans colony growth in sector 1 to 3 , which is similar to sector 9 , the negative control. The colony growth is started from sector 4 and getting more apparent in sector 5, 6, 7, and 8, like in sector 10 which is the positive control (Fig. 1.)

The determination of MIC of the quaternary ammonium and EDTA mixture towards C. albicans isolates present a result as shown in Table 2 .

Based on the MIC examination results, a contact time testing in $1 / 2000,1 / 4000$, and $1 / 8000$ concentrations with a contact time of $1 / 4$ hour, $1 / 2$ hour, 1 hours, 2 hours, 4 hours, and 8 hours was performed. The results of the observation are as listed in the following table:

Based on the further test performed, it turns out that there is no significant differences between tube 1, 2, 3 and the negative control. However, there is a significant difference with the positive control. Tube 4 , when it is compared to negative and positive controls, shows no significant difference. Other tubes, i.e. 5, 6, 7 and 8, show a significant difference with the negative control but no significant difference with the positive control.

Based on further examination, it can be analyzed that the two treatments differ significantly for $C$. albicans in terms of contact time of the quaternary ammonium and EDTA mixture while other treatments show no significant difference.

\section{DISCUSSION}

The observation results form the sectoral culturing show that there are various effects of different quaternary ammonium and EDTA mixture concentrations towards $\mathrm{C}$. albicans growth. The smaller the concentration of the quaternary ammonium and EDTA mixture, the higher the $C$. albicans growth. The concentration level of the disinfectant is inversely comparative with the microorganism growth.

The MIC test results for quaternary ammonium and EDTA mixture towards $C$. albicans seen in sectoral culturing (Tab. 2 ) give a result that MIC in the first sample is $1 / 16000$, the second sample is $1 / 32000$, while the third, fourth and fifth sample is $1 / 8000$. The C. albicans growth is started in $1 / 8000$ concentration and reaches $60 \%$. Therefore, it can be described that the MIC of quaternary ammonium and EDTA mixture towards the $C$. albicans isolates is $1 / 8000$.

The MIC test results shown by the first and second samples are different with the MIC gained from the third, fourth and fifth samples.

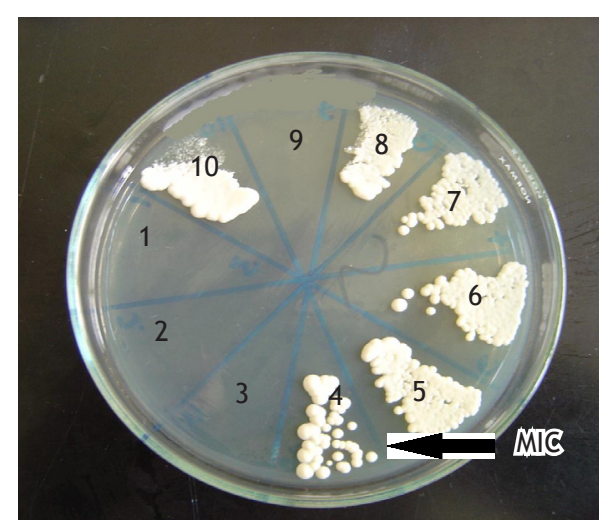

Figure 1. MIC determination based on observation of Candida albicans growth in Saboraud Glucose Agar. 
Table 2. The results of sectoral Candida albicans culture in SGA with various quaternary ammonium and EDTA mixture concentrations.

\begin{tabular}{|c|c|c|c|c|c|c|c|c|c|c|c|}
\hline \multirow{2}{*}{ Fungal test } & \multirow{2}{*}{ Repeated } & \multicolumn{10}{|c|}{ Tube } \\
\hline & & 1 & 2 & 3 & 4 & 5 & 6 & 7 & 8 & $K(-)$ & $\mathrm{K}(+)$ \\
\hline & A & - & - & - & - & \pm & + & + & + & - & + \\
\hline \multirow[t]{3}{*}{1} & B & - & - & - & - & \pm & + & + & + & - & + \\
\hline & C & - & - & - & - & \pm & + & + & + & - & + \\
\hline & A & - & - & - & - & - & \pm & + & + & - & + \\
\hline \multirow[t]{3}{*}{2} & B & - & - & - & - & - & \pm & + & + & - & + \\
\hline & C & - & - & - & - & - & \pm & + & + & - & + \\
\hline & A & - & - & - & - & \pm & + & + & + & - & + \\
\hline \multirow[t]{3}{*}{3} & B & - & - & - & - & \pm & + & + & + & - & + \\
\hline & C & - & - & - & - & \pm & + & + & + & - & + \\
\hline & A & - & - & - & - & \pm & + & + & + & - & + \\
\hline \multirow[t]{3}{*}{4} & B & - & - & - & - & \pm & + & + & + & - & + \\
\hline & C & - & - & - & - & \pm & + & + & + & - & + \\
\hline & A & - & - & - & - & \pm & + & + & + & - & + \\
\hline \multirow[t]{2}{*}{5} & B & - & - & - & - & \pm & + & + & + & - & + \\
\hline & C & - & - & - & - & \pm & + & + & + & - & + \\
\hline
\end{tabular}

Notes: Quaternary ammonium and EDTA mixture concentration in the tube:1:1/1000; 2:1/2000; 3:1/4000; 4:1/8000; 5:1/16000; 6:1/32000; 7:1/64000; 8:1/128000; K(-):Negative control; K(+): Positive control; (-): No C. albicans growth; ( \pm ): Starting to show C. albicans growth; (+): Show C. albicans growth.

Table 3. The results of Candida albicans culture in SGA with various concentrations and contact times.

\begin{tabular}{|c|c|c|c|c|c|c|c|c|}
\hline \multirow{2}{*}{ Fungal test } & \multirow{2}{*}{ Repeated } & \multirow{2}{*}{ Concentration } & \multicolumn{6}{|c|}{ Contact time (hour) } \\
\hline & & & $1 / 4$ & $1 / 2$ & 1 & 2 & 4 & 8 \\
\hline 1 & $A, B, C$ & & ++ & ++ & ++ & ++ & ++ & + \\
\hline 2 & $A, B, C$ & & ++ & ++ & ++ & ++ & ++ & + \\
\hline 3 & $A, B, C$ & $1 / 8000$ & ++ & ++ & ++ & ++ & ++ & + \\
\hline 4 & $A, B, C$ & & ++ & ++ & ++ & ++ & ++ & + \\
\hline 5 & $A, B, C$ & & ++ & ++ & ++ & ++ & ++ & + \\
\hline 1 & $A, B, C$ & & ++ & ++ & ++ & ++ & ++ & + \\
\hline 2 & $A, B, C$ & & ++ & ++ & ++ & ++ & ++ & + \\
\hline 3 & $A, B, C$ & $1 / 4000$ & ++ & ++ & ++ & ++ & ++ & + \\
\hline 4 & $A, B, C$ & & ++ & ++ & ++ & ++ & ++ & + \\
\hline 5 & $A, B, C$ & & ++ & ++ & ++ & ++ & ++ & + \\
\hline 1 & $A, B, C$ & & ++ & ++ & ++ & ++ & ++ & + \\
\hline 2 & $A, B, C$ & & ++ & ++ & ++ & ++ & ++ & + \\
\hline 3 & $A, B, C$ & $1 / 2000$ & ++ & ++ & ++ & ++ & ++ & + \\
\hline 4 & $A, B, C$ & & ++ & ++ & ++ & ++ & ++ & + \\
\hline 5 & $A, B, C$ & & ++ & ++ & ++ & ++ & ++ & + \\
\hline
\end{tabular}

Notes: (++): Unable to calculate $\mathrm{C}$. albicans growth; (+): C. albicans growth $\leq 300$ colonies

This may be caused by the differences in microorganism sensitiveness that is affected by the subject's oral cavity or the food or medication consumed by the subject. The limitation of the operator in doing this study may also be one of the causal factors that may affect the results of the study.

Based on the statistical analysis towards 
the study data for the contact time in Table 3, all samples give the same influence towards each concentration of quaternary ammonium and EDTA mixture $(1 / 8000,1 / 4000$, and $1 / 2000)$ and the contact times tested $(0.25$ hour, 0.50 hour, 1 hour, 2 hours, 4 hours, and 8 hours) with all showing $C$. albicans colony growth.

When a comparison is performed on the number of colonies in the five samples, in $1 / 8000$ concentration all samples give the same influence for all contact times tested $(0.25$ hour, 0.50 hour, 1 hour, 2 hours, 4 hours, and 8 hours), with many C. albicans colonies that are dense and difficult to count.

In 1/4000 concentration, all samples show many $C$. albicans colonies that grow densely and difficult to count at the contact times of 0.25 hour, 0.50 hour, 1 hour, 2 hours, and 4 hours. The situation is also seen at the contact time of 8 hours in the third, fourth and fifth samples while the first and the second samples show a colony growth that can be counted, i.e. $\leq 300$ colonies.

In 1/2000 concentrations, all samples show 0.25 hour, 0.50 hour, 1 hour, 2 hours, and 4 hours. At the contact time of 8 hours, all samples show a colony growth that can be counted, i.e. $\leq 300$ colonies.

The conclusion from the above comparison is that the quaternary ammonium and EDTA mixture in $1 / 2000$ concentration gives a better result in decreasing the number of $C$. albicans colonies. The concentration is recommended as the usage concentration for soaking artificial denture. This is to avoid unwanted dilution from excess water during cleaning before soaking the artificial denture.

According to the statistical calculation, all contact times give similar effects to each sample. Therefore the utilization of this solution as the solution for soaking artificial denture is set into the longest duration and nearest situation that imitate people's habit in soaking denture, i.e. 8 hours.

The concentration of quaternary ammonium and EDTA mixture used in this study is very small that it even needs 1000 times dilution from the available standard solution. This shows that the antifungal quaternary ammonium and EDTA mixture is very effective for killing $C$. albicans in a very low concentration. In terms of the economic value, the use of this disinfectant is very beneficial.

\section{CONCLUSION}

From the discussion above it can be concluded that the minimum inhibitory concentration of quaternary ammonium and EDTA mixture towards C. albicans isolates is $\geq 1 / 8000$ with an effective contact time of $\geq 8$ hour.

\section{REFERENCES}

1. Sunarintyas S. Lama pembersihan efisien papain pada pelepasan plak gigi tiruan. J Kedokteran Gigi Universitas Indonesia 2003; 10(ed khusus):211-5.

2. Burton GRW, Engelkirk PG. Microbiology for the health sciences. $5^{\text {th }}$ ed. New York: Lippincott; 1996.

3. Silverman S, Eversole LR, Truelove EL. Essentials of oral medicine. London: BC Decker Inc.; 2002.

4. Greenberg MS, Glick M. Burket's oral medicine diagnosis and treatment. $10^{\text {th }}$ ed. Ontario: $B C$ Decker Inc.; 2003.

5. Miller $\mathrm{CH}$, Palenik CJ. Infection control and management of hazardous materials for the dental team. St. Louis: Mosby; 2005.

6. Munadziroh E, Indrasari M. Bahan pembersih gigi tiruan untuk mencegah pertumbuhan Candida albicans. Dental J 2001;34(3a):2001. p. 213-6.

7. Sheen SR, Harrison A. Assesment of plaque prevention on denture using an experimental cleanser. J Prosthet Dent 2000(84):594-601.

8. Schunack W, Mayer K, Haake M. Senyawa obat, Buku pelajaran kimia farmasi. Edisi kedua. Yogyakarta: Gadjah Mada University Press; 1990.

9. Newman MG, Kornman KS. Antibiotic/ antimicrobial use in dental practice. Chicago: Quintessence Publishing Co. Inc.; 1990.

10. Mutschler E. Dinamika obat buku ajar farmakologi dan toksikologi. Bandung: Penerbit ITB; 1999.

11. Tan HT, Rahardja K. Obat-obat penting. Jakarta: Elex Media Computindo; 2002.

12. Russell AD, Hugo WB, Ayliffe GAJ. Principles and practice of disinfection, preservation, and sterilization. $4^{\text {th }}$ ed. United Kingdom: Blackwell 
Publishing; 2004.

13. Yagiela JA, Dowd FJ, Neidle EA. Pharmacology and therapeutics for dentistry. $5^{\text {th }}$ ed. St. Louis: Mosby; 2004.

14. Lawrence CA, Block SS. Disinfection, sterilization, and preservation. Philadelphia: Lea \& Febiger; 1971.
15. Goodman LS, Gillman A. The pharmacological basis of therapeutics. $10^{\text {th }}$ ed. New York: The Macmillan Co.; 2001.

16. Hugo WB, Russel AD. Pharmaceutical microbiology. England: Blackwell Scientific Publication; 1977.

17. Katzung BG. Farmakologi dasar dan klinik. Edisi 6. Jakarta: EGC; 1998. 